Systematic Botany (2005), 30(4): pp. 750-758

(C) Copyright 2005 by the American Society of Plant Taxonomists

\title{
Pollen Evolution in Yams (Dioscorea: Dioscoreaceae)
}

\author{
Peter Schols, $, 1,3$ Paul Wilkin, ${ }^{2}$ Carol A. Furness, ${ }^{2}$ Suzy Huysmans, ${ }^{1}$ and Erik Smets ${ }^{1}$ \\ ${ }^{1}$ Laboratory of Plant Systematics, Institute of Botany and Microbiology, K.U.Leuven, Kasteelpark Arenberg 31, \\ B-3001 Leuven, Belgium; \\ ${ }^{2}$ Royal Botanic Gardens, Kew, Richmond, Surrey, TW9 3AB, U.K.; \\ ${ }^{3}$ Author for correspondence (peter.schols@bio.kuleuven.ac.be)
}

Communicating Editor: Alan W. Meerow

\begin{abstract}
Pollen character evolution in yams (Dioscorea: Dioscoreaceae) was investigated in relation to the phylogeny obtained from a recent combined analysis of $r b c L$ and $m a t K$ gene sequences. The following characters were evaluated: pollen size, aperture number, sexine ornamentation, perforation density, and orbicule presence or absence. Continuous characters were coded using the gap weighting method. Each character was optimized using MacClade onto a tree selected at random from analyses based on molecular data of Wilkin et al. The results indicate that in Dioscorea pollen size decreases in the more derived clades. The latter observation may be related to the evolution of annually replaced tubers. Aperture number increases from one in the monosulcate Stenophora clade (sister to the rest of Dioscorea) to two in other Dioscorea clades. This may be related to the presence of simultaneous microsporogenesis in Dioscorea. A perforate sexine is plesiomorphic in Dioscorea and a striate pattern has evolved more than once and is particularly characteristic in the Malagasy clade. Sexine ornamentation in the Stenophora clade is diverse. The endemic allotetraploid D. pyrenaica is characterized by large, monosulcate, gemmate pollen. The Dioscorea B clade is characterized by pollen with small, dense perforations. Orbicules occur in all Dioscorea species, but are absent in most of the outgroup taxa.
\end{abstract}

Su (1987), Caddick et al. (1998), and Xifreda (2000) were the first to suggest the possible taxonomic significance of pollen morphology within Dioscoreaceae, a family of about 450 species growing in humid tropical and subtropical areas. Their work indicated that Dioscorea L., the yam genus to which $90 \%$ of all Dioscoreaceae belong, was palynologically diverse. Following these preliminary studies, Schols et al. $(2001,2003)$ examined pollen of 96 Dioscorea species with light microscopy (LM) and scanning (SEM) and transmission electron microscopy (TEM). They described pollen of Dioscorea as monosulcate or disulculate, with a mainly perforate, perforate to microreticulate or striate sexine. They also found aperture number and sexine ornamentation to be frequently consistent within samples from each section. Pollen characters indicated support for the relationship between some existing infrageneric taxa, for example D. sect. Asterotricha and D. sect. Enantiophyllum Uline originally proposed by Burkill (1960), and between D. sect. Botryosicyos (Hochst.) Uline and D. Sect. Lasiophyton Uline.

Concurrently, Wilkin et al. (2005) expanded the Dioscoreaceae $r b c L$ data set of Caddick et al. (2002) and added $m a t K$ sequences to it. Using these data, they presented the first infrageneric phylogenetic hypothesis for Dioscorea. The general tree topology of this combined molecular analysis is as follows. The outgroups, selected on the basis of the earlier analysis of Dioscoreales by Caddick et al. (2002), are representatives of the heteromycotrophic family Burmanniaceae and the Dioscoreaceae with hermaphrodite flowers (Stenomeris Planch., Trichopus Gaertn, and Tacca J.R. \& G.Forst). The exclusively rhizomatous $D$. sect. Stenophora Uline is sister to the rest of Dioscorea, followed by two New
World clades, one of which includes Dioscorea longirhiza Caddick \& Wilkin, formerly in the genus Nanarepenta Matuda. Next, there is a southern and montane African clade consisting of D. sylvatica Eckl. and related species, and a European clade comprising former Tamus L. species and D. pyrenaica Bubani \& Bordère ex Gren., although support for the latter clade in particular is weak. The B clade of Dioscorea contains almost all Old World species, with the exception of Rajania (Dioscorea) cordata L. Two strongly supported subclades are nested within it, one of which comprises endemic Malagasy taxa. The other is the right-twining D. sect. Enantiophyllum.

This molecular phylogenetic framework enables us to trace the evolution of pollen morphology within Dioscorea. Pollen characters have been assessed in a phylogenetic context previously by several workers, including Rudall et al. (1997), Furness and Rudall (2000, 2001), Doyle et al. (2000), Cameron et al. (2001), and Sauquet and Le Thomas (2003). Most of these studies dealt with pollen evolution within a family or at higher levels. Schols et al. (2001, 2003) found significant variation in pollen morphology of Dioscorea. However, studies of the evolution of pollen characters within a genus are comparatively rare even for large genera. Thus our work on Dioscorea may indicate the potential for using such methods in the systematics of large genera.

\section{MATERIALS AND MetHODS}

Pollen Characters. A complete list of Dioscorea and Tacca specimens for which pollen and anthers were examined is given in Appendix 1. Descriptions of the methods used are given in Schols et al. (2001, 2003). Measurements of pollen perforation density and perforation size were carried out on digital SEM images using 
Carnoy 2.1 for Mac OS X (Schols et al. 2002). Terminology follows the international glossary (Punt et al. 1998). All Dioscorea pollen data are based on observations by Schols et al. (2001, 2003). Data for Rajania cordata are from Raz et al. (2001). For the outgroup taxa, data for Tacca are based on observations by the first author (P. Schols, unpubl. data). Data for other Dioscoreaceae with hermaphrodite flowers are from Caddick et al. (1998), and data for Burmanniaceae are from Chakrapani and Raj (1971), Rübsamen (1986), and Caddick et al. (1998).

Three continuous characters (pollen size, perforation density, and perforation size) were coded using Thiele's gap weighting method as implemented by MorphoCode (Schols et al. 2004), with $\mathrm{n}=10$, where $\mathrm{n}$ is the number of allowed character states in the Thiele formula (Thiele 1993). MorphoCode offers the user the possibility to import data as tab-separated text, choose the number of character states, perform all necessary calculations and export the newly coded data to a Nexus file. MorphoCode and its source are available free on the MorphoCode website: www.kuleuven.ac. be/bio/sys/mc under the GNU GPL. To compensate for the high weight (10) all continuous characters receive as a result of the gap weighting method, the continuous characters were assigned a weight of $0.1(=1 / 10)$, in order to give them a maximum length equal to the other characters. Non-continuous data were treated as unordered multistate characters (aperture number, ornamentation type, presence or absence of orbicules) and were assigned the default weight of 1 .

Character Optimization. Since Wilkin et al. (2005) have obtained a stable overall topology, we felt confident optimising pollen characters onto the trees at this stage of our research. Characters were optimized on one of the 15868 most parsimonious trees chosen at random from the combined $r b c L$ and mat $K$ analysis of Wilkin et al. (2005) using DELTRAN in MacClade 4 (Maddison and Maddison 2001). Adding the pollen characters to the matrix of $r b c L$ and $m a t K$ sequences and running a new analysis produced a strict consensus tree of identical topology to that presented by Wilkin et al. (2005) and had only a minor influence on the support indices (results not shown here). Therefore, we decided to optimise the pollen characters on the molecular tree. It should be remembered that the sampling of taxa in Wilkin et al. (2005) is biased towards Old World taxa, particularly Thailand and Madagascar. Due to coding the continuous characters with Thiele's gap weighting method, they have a large number of states (see Schols et al. 2004 for an explanation of the gap-weighting method).

\section{RESUltS}

Four trees are presented each showing a single pollen character (Figs. 1-4). Perforation size (not shown) was also optimized but lacked congruence with the phylogeny.

\section{DISCUSSION}

Pollen Size (Figs. 1, Fig. 5A). Pollen size is a rather homoplasious character, as may be expected (Fig. 1). Among the outgroup taxa, Tacca is distinguished by large pollen (about $50 \mu \mathrm{m}$ ). Within Dioscorea, D. nipponica in the Stenophora clade has large pollen, although most Stenophora and New World species sampled are of intermediate size. Large pollen characterizes the southern/montane African clade and D. pyrenaica from the European clade. The former includes taxa with large perennial tubers (e.g., D. elephantipes). $\mathrm{Su}$ (1987) proposed that Dioscorea species with perennial tubers or rhizomes have larger pollen grains and this correlation was shown to be statistically significant by Schols et al. (2001, 2003). The reasons for this are not known, although resource allocation in yams could be a useful area for future work. Dioscorea pyrenaica, an endemic from the Pyrenees, was recently shown to be an allotetraploid, which may correlate with large pollen size (Segarra-Moragues and Catalán in press). Within the B clade, there are fewer taxa with large pollen, for example D. pseudonitens in the Birmanica clade. In the Malagasy clade, $D$. fandra, which is sister to the rest of the more diversified subclade, has large pollen. The pollen grains of the rest of the more diversified subclade are smaller, as are those of the only member of the $D$. arcuatinervis-D. bemarivensis clade sampled, $D$. arcuatinervis. This suggests that evolution has mainly acted to reduce pollen size in Madagascar. Large pollen is absent from the rest of the B clade, which have pollen of less than $30 \mu \mathrm{m}$ (Fig. 5A). It is difficult to find reasons for this, although a it may be correlated with possession of annually replaced tubers in the B clade and in turn the ability to colonise a wider range of habitats (Burkill 1960). The cost of the flexibility afforded by an annually replaced tuber may be less resources available for reproduction.

Aperture Number (Fig. 2, Fig 5A). The outgroup taxa and the Stenophora clade have a single pollen aperture, with two apertures characterizing the majority of Dioscorea species (Fig. 2). In the outgroup, Burmannia madagascariensis and B. longifolia are ulcerate while the monoecious Dioscoreaceae are monosulcate, with the exception of Trichopus sempervirens, which is 4- or 5pantoporate (Caddick et al. 1998). Most Dioscorea species are disulculate and disulculate pollen clearly evolved only once in Dioscorea (Figs. 2, Fig. 5A). Exceptions are the Stenophora clade and D. pyrenaica (Fig. $2)$. The Stenophora clade is exclusively monosulcate (Fig. 5A) and D. birmanica, a disulculate species placed in section Stenophora by Prain and Burkill (1936), is a member of the B-clade. Schols et al. (2003) previously suggested it was misplaced in section Stenophora on the basis of pollen morphology. Interestingly, the monosulcate D. pyrenaica is a polyploid (see above: Pollen Size), which may explain the occurrence of atypical pollen here. In a few species (e.g., D. fandra and D. hexagona) the majority of the pollen is disulculate with smaller, collapsed and wrinkled monosulcate grains forming a low percentage (below 5\%: Schols et al. 2001, 2003). Possibly this monosulcate pollen is sterile although this requires further testing.

Evolution of pollen aperture number from low to higher numbers has been suggested previously for several groups, for example, Alismatales (Chanda et al. 1988), monocotyledons (Zavada 1983), and eudicots (Van Campo 1976). Experimental evidence demonstrates that increased aperture number may confer a selective advantage in Viola species (Dajoz et al. 1991) because it increases the number of prospective germination sites, thus facilitating contact between at least 


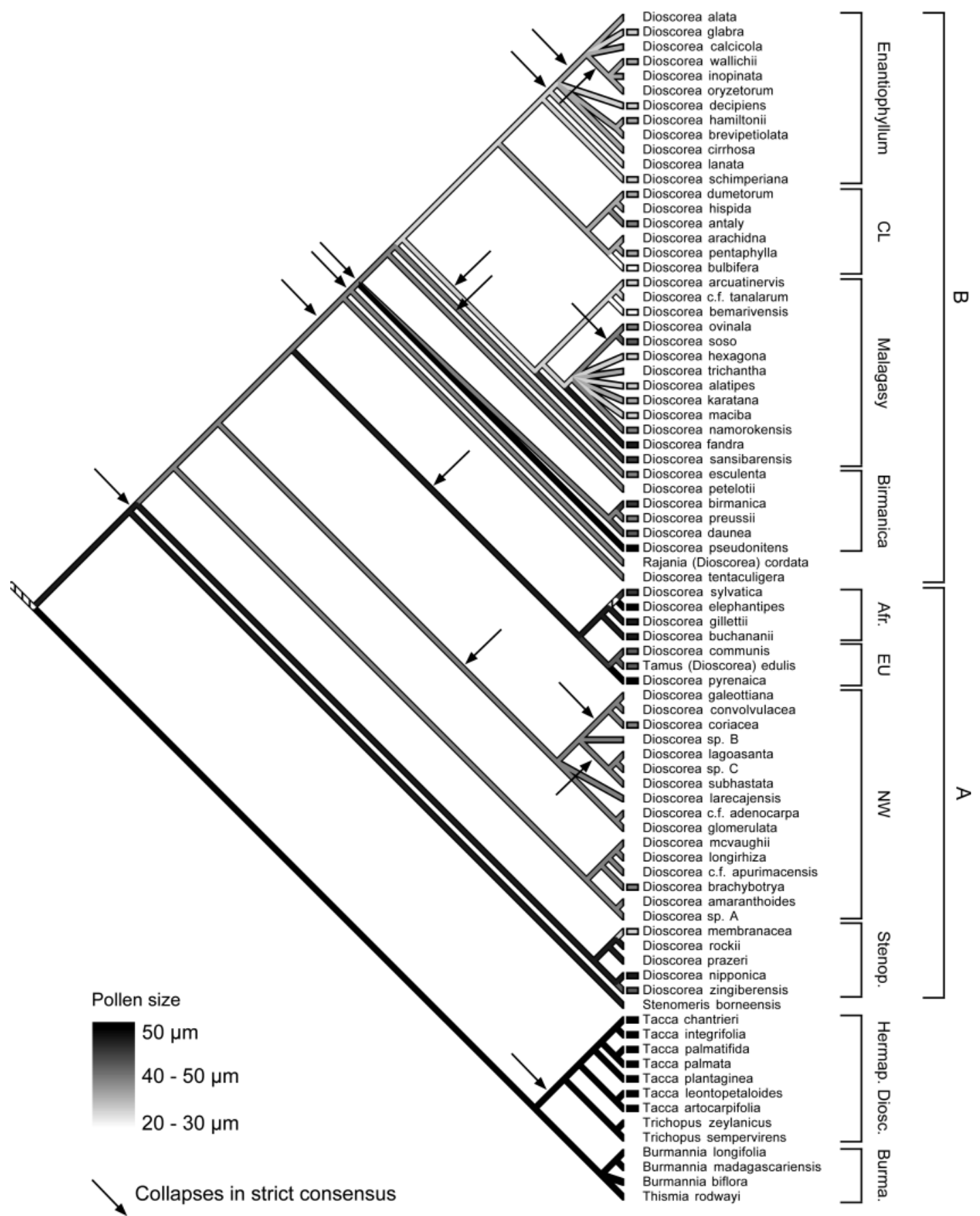

FIG. 1. Pollen size (length of longest axis) optimised onto one of the 15868 most parsimonious trees of Wilkin et al. (2005). As a result of the gap-weighting (Schols et al. 2004) pollen size is represented on a continuous scale, with darker branches representing larger pollen grains. Branches labeled with an arrow collapse in the strict consensus.

one aperture and the stigmatic surface. The increase in aperture number from one to three may be a critical factor in eudicot success (Furness and Rudall, 2004). It has been proposed that pollen aperture number and pattern is related to microsporogenesis (e.g., Black- more and Crane 1998) and a correlation between simultaneous microsporogenesis and trichotomosulcate apertures has been demonstrated in Asparagales (Rudall et al. 1997). Based on experimental work on $\mathrm{Ni}$ cotiana, Ressayre et al. (2002) proposed that simulta- 


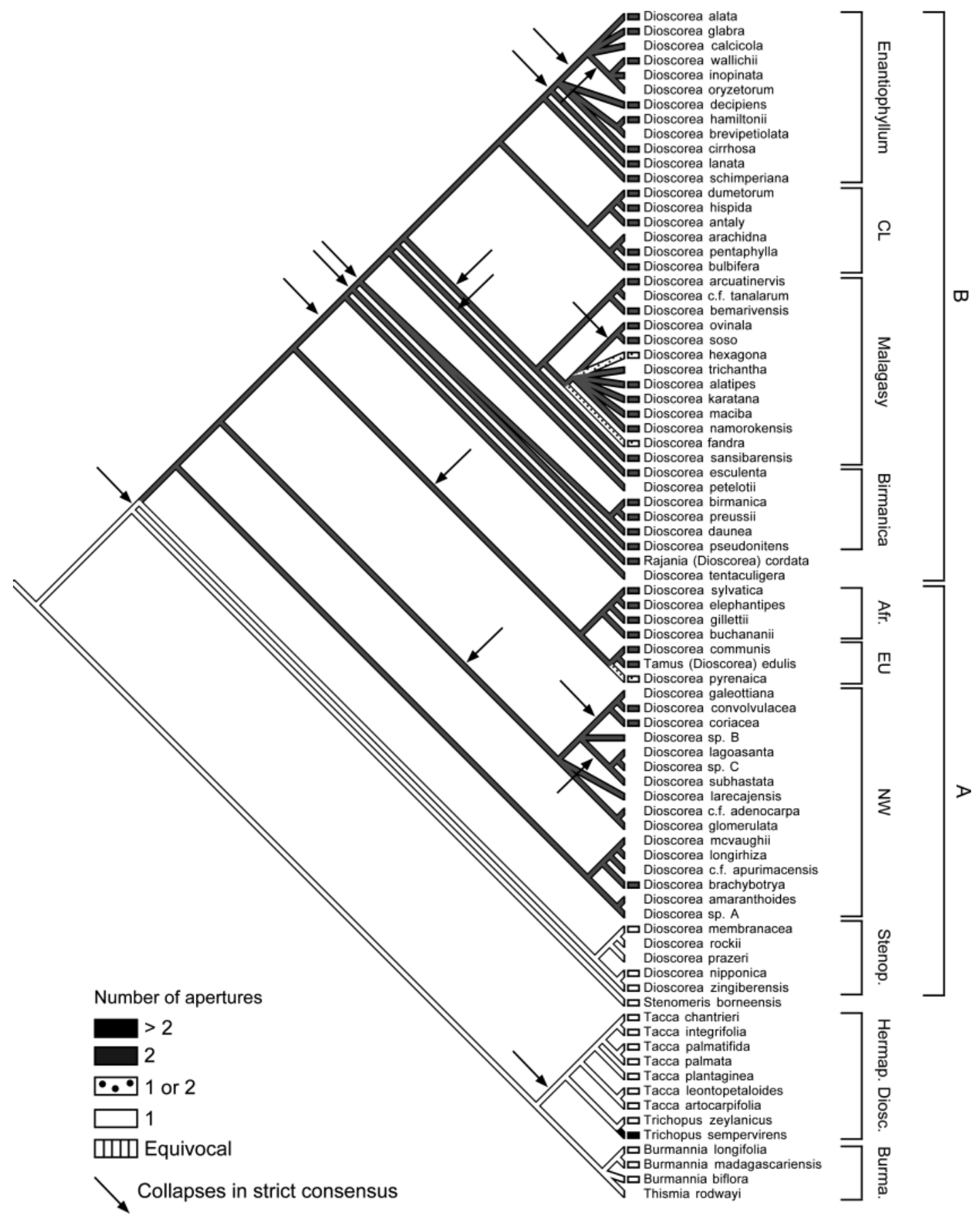

FIG. 2. Aperture number optimised onto one of the 15868 most parsimonious trees of Wilkin et al. (2005). Branches labeled with an arrow collapse in the strict consensus.

neous cytokinesis allows variation in the interaction between nuclei, which is impossible in successsive microsporogenesis, thus leading to heteromorphic pollen. Changes in aperture number are thus potentially easy to achieve. Microsporogenesis is succcessive in most monocotyledons, although the simultaneous type has arisen several times independently within the group (Furness and Rudall 1999, 2000). Within Dioscoreales, Nartheciaceae and Burmanniaceae have successive microsporogenesis and Dioscoreaceae are simultaneous (Caddick et al. 1998; Furness and Rudall 1999, 2000). The shift from successive to simultaneous microspo- 


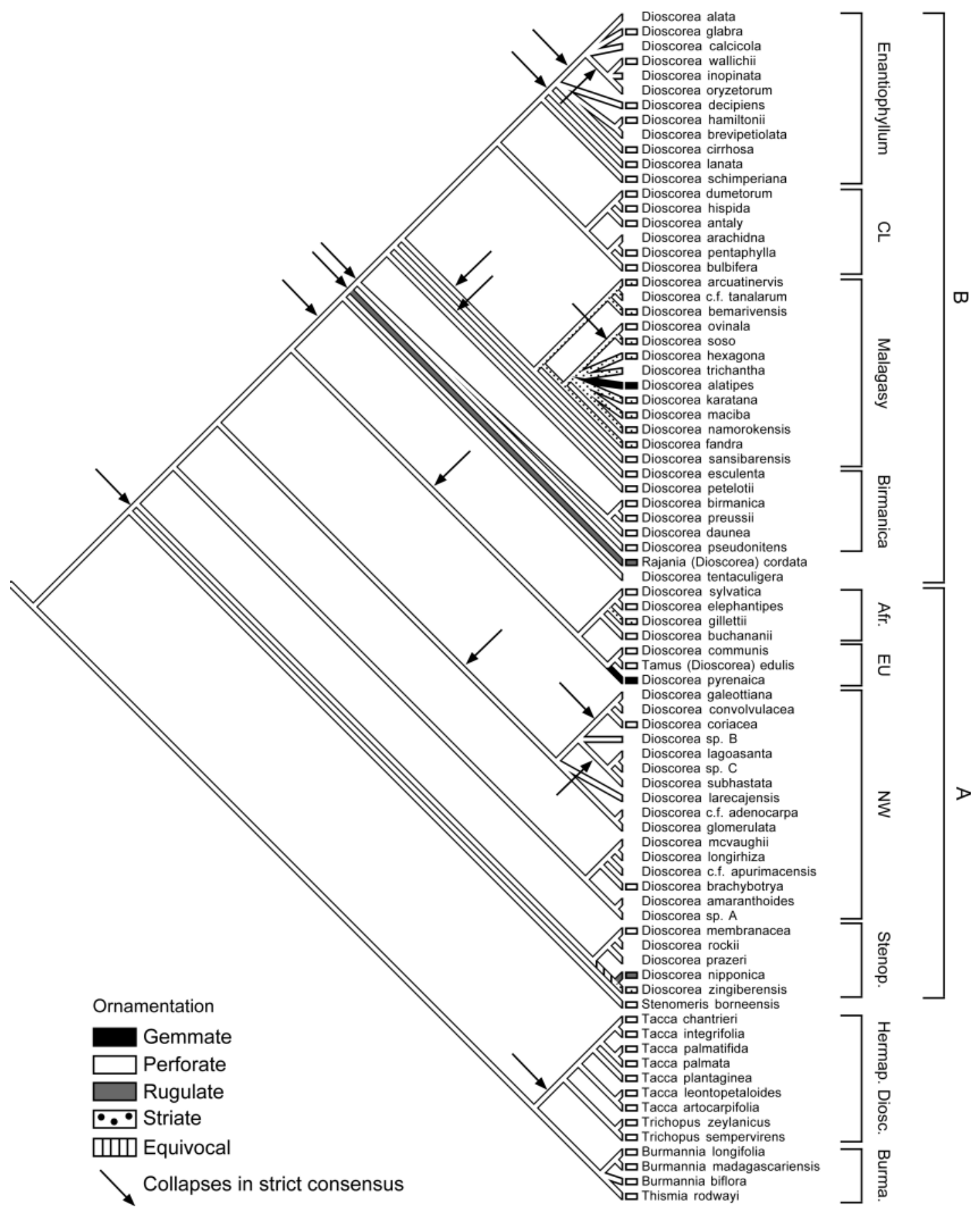

FIG. 3. Sexine ornamentation optimised onto one of the 15868 most parsimonious trees of Wilkin et al. (2005). Branches labeled with an arrow collapse in the strict consensus.

rogenesis precedes the shift from monosulcate to disulculate pollen (Fig. 2) and may have facilitated the switch to two apertures. The existence of several species with heteromorphic pollen (one or two apertures) also indicates that this change was relatively easy and is in agreement with Ressayre's (2002) hypothesis. In
Dioscorea pollen the change to two apertures appears to be irreversible, probably becoming fixed by a selective advantage confered by more than one potential germination site. However, some monocots with successive microsporogenesis have multiple apertures. Some Alismatales (Chanda et al. 1988) and the Bur- 


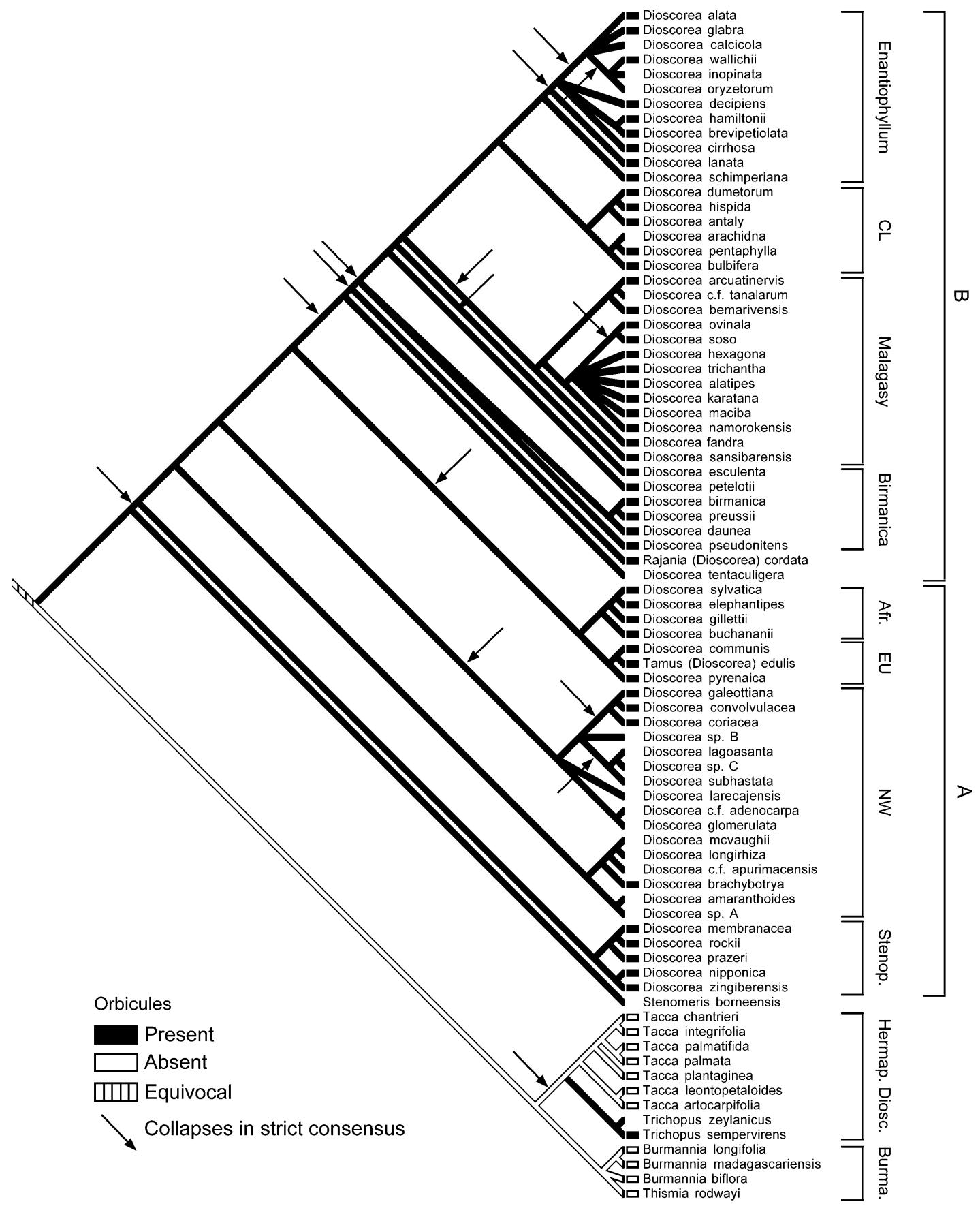

FIG. 4. Orbicule presence optimised onto one of the 15868 most parsimonious trees of Wilkin et al. (2005). Branches labeled with an arrow collapse in the strict consensus.

manniaceae genera Dictyostega and Thismia (Chakrapani and Raj 1971; Rübsamen 1986), and Pontederiaceae (Commelinales) are successive and disulculate (Simpson 1987; Ressayre 2001).

Sexine Ornamentation (Figs. 3, 5B-G). A perforate sexine is plesiomorphic and occurs throughout the outgroup and in the majority of Dioscorea species sampled
(Fig. 3). Perforation size and density vary (see below: Perforation Density). The perforate sexine type includes perforate to microreticulate (e.g., D. antaly) since both ornamentation types are observed in the same grain (Schols et al. 2003).

Striate ornamentation, which is relatively uncommon in the monocotyledons (Van der Ham 1998), is 

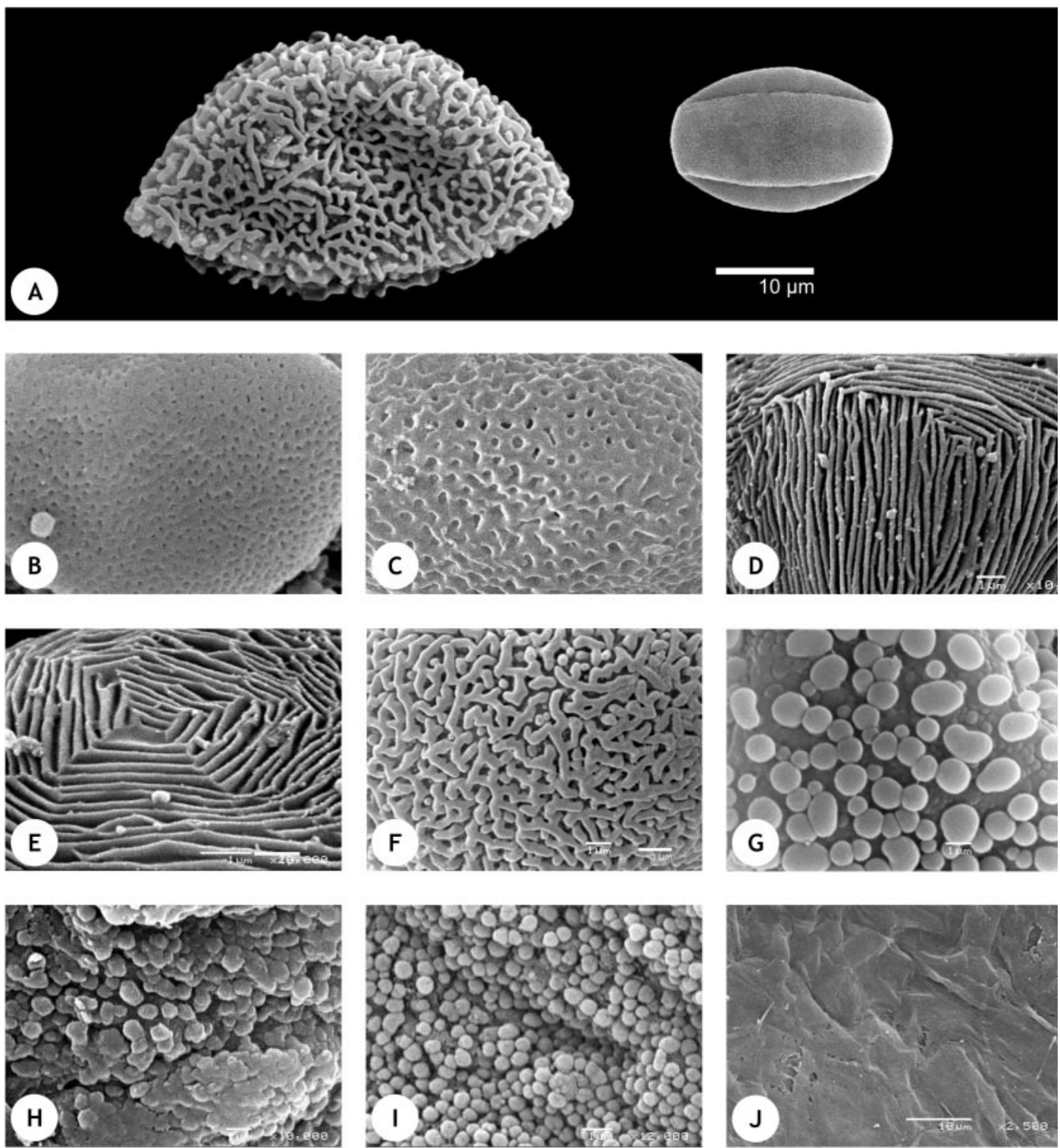

FIG. 5. Pollen characters (SEM). A. Left: D. nipponica (Stenophora), monosulcate pollen grain with longest axis of $45 \mu \mathrm{m}$. Right: D. hamiltonii (Enantiophyllum), disulculate pollen grain with longest axis of $20 \mu \mathrm{m}$. B. D. bulbifera (CL), perforate sexine with small perforations. C. D. membranecea (Stenophora) perforate sexine. D. D. karatana, striate sexine. E. D. bemarivensis (Malagasy), striate sexine with striations arranged in concentric polygons. F. D. nipponica (Stenophora), rugulate sexine. G. D. pyrenaica (EU), gemmate sexine. H. D. glabra (Enantiophyllum), spherical to elliptical orbicules. I. D. sylvatica (Afr.), spherical orbicules. J. Tacca plantaginea, tapetal remnants at anthesis without orbicules.

found in D. zingiberensis in the Stenophora clade, in $D$. gillettii and in almost all Malagasy species sampled, except $D$. antaly in the CL clade (Figs. 3, 5D). A striate sexine also occurs in some New World yams and in some Rajania species (Xifreda 2000; Raz et al. 2001; Schols et al. 2001, 2003). These taxa are not included in our analysis due to absence of molecular data. It appears that the striate pattern has arisen independently several times within Dioscorea. The fact that the striae in Stenophora and the African clade are almost twice as wide as those in the Malagasy clade supports this (Schols et al. 2003). There appears to be a single origin for the striate pattern in the Malagasy clade, which is divided into two well-supported sub-clades (Wilkin et al., 2005). In the first, a gemmate sexine has evolved in $D$. alatipes with a reversal to the perforate condition in D. ovinala. The second sub-clade containing $D$. arcuatinervis and related species is characterised by striae arranged in concentric polygons (Fig. 5E).

A rugulate sexine occurs in D. nipponica in the Ste- 
nophora clade (Fig. 5F). All three Stenophora species sampled have a different ornamentation type (striate, rugulate and perforate), indicating a high level of diversity in this clade. Other Stenophora species examined by Schols et al. $(2001,2003)$ and not included in the analysis also have a variety of sculpturing types. Possibly sexine ornamentation is less fixed here. The New World Rajania (Dioscorea) cordata also has rugulate ornamentation, as do some New World Dioscorea species not included in the analysis (Xifreda 2000; Schols et al. 2003), although the rugulate pattern in these taxa does not look like that of $R$. cordata and is therefore unlikely to be homologous.

Gemmae have evolved twice, in the Malagasy D. alatipes (see above) and European D. pyrenaica, a polyploid with atypical pollen discussed previously (Fig. $5 \mathrm{G})$. The gemmae differ in mean diameter, those of $D$. alatipes are about $0.4 \mu \mathrm{m}$ and those of D. pyrenaica about $1.2 \mu \mathrm{m}$, supporting their independent origin. Dioscorea pyrenaica is ant pollinated and the gemmate ornamenation here could possibly be a related adaptation (Garcia et al. 1995; Caddick et al. 1998).

Perforation Density (Figs. 5B-C). High perforation density (more than 8 perforations per $\mu \mathrm{m}^{2}$ ) is restricted to the Dioscorea B clade, in D. dumetorum, D. bulbifera, D. pentaphylla and the Enantiophyllum clade. Pollen here tends to be smaller (see Pollen Size) with small, dense perforations. A low perforation density (less than 5 perforations per $\mu \mathrm{m}^{2}$ ) however occurs in $D$. antaly. Most other perforate Dioscorea species have moderate (between 5 and 8 perforations per $\mu \mathrm{m}^{2}$ ) densities. No tree is shown for this character as there are not enough observations.

Orbicules (Figs. 4, 5H-J). Orbicules-small sporopollenin bodies found in the anther locule-occur throughout Dioscorea (Figs. 4, 5H, I). Orbicules in Dioscorea are mostly spherical but are sometimes elliptical, irregularly shaped or spiny. They are found on the tangential and radial walls of the tapetal cells (Schols et al. 2001, 2003). Orbicules are associated with secretory tapeta (Huysmans et al. 1998) which occur throughout Dioscoreales (Furness and Rudall 1998). Orbicules are however absent from the outgroup taxa Tacca (Fig. 5J; P. Schols, pers. obs.) and Burmaniaceae, which is unusual for taxa with secretory tapeta, although they are present in Trichopus sempervirens (L. R. Caddick, pers. comm.).

This study shows that pollen characters can contribute to the systematics of large genera. Most of the palynological characters discussed in this paper show at least some congruence with the plastid gene phylogeny. For example, there is a trend to smaller pollen grains in more derived Dioscorea clades and a shift from monosulcate pollen in the basal Stenophora clade to disulculate pollen grains in the remainder of the genus. Orbicules occur in almost every Dioscorea spe- cies but are absent from all representatives of Tacca. In future, further sampling of pollen, especially New World taxa, will help to give a complete picture of the diversity and relationships in Dioscorea. Studies of pollen development, especially pollen apertures, may help to understand the shift from monosulculate to disulculate apertures in Dioscorea between the Stenophora clade and the rest of the genus.

ACKNOWLEDGEMENTS. We are grateful to Dr. Eric Schoeters, Marcel Verhaeghen, and Anja Vandeperre for technical assistance. Suzy Huysmans is a Postdoctoral Fellow of the Fund for Scientific Research-Flanders (Belgium). Peter Schols holds a research grant from the IWT (no. 991293). This research is supported by a grant from the Research Fund of the K.U.Leuven (OT/01/25).

\section{LiterATURE Cited}

Blackmore, S. and P. R. CRANe. 1998. The evolution of apertures in the spores and pollen grains of embryophytes. Pp. 159182 in Reproductive biology in systematics, conservation and economic botany, eds. S. J. Owens and P. J. Rudall. Kew: Royal Botanic Gardens.

BURKILL, I. H. 1960. The organography and the evolution of the Dioscoreaceae, the family of the yams. Botanical Journal of the Linnean Society 56: 319-412.

Caddick, L. R., C. A. Furness, K. L. Stobart, and P. J. Rudall. 1998. Microsporogenesis and pollen morphology in Dioscoreales and allied taxa. Grana 37: 321-336.

, P. J. Rudall, P. Wilkin, T. A. J. Hedderson, and M. W. CHASE. 2002. Phylogenetics of Dioscoreales based on combined analyses of morphological and molecular data. Botanical Journal of the Linnean Society 138: 123-144.

Cameron, K. L., M. W. Chase, W. R. Armstrong, and H. G. HiLLS. 2001. Molecular systematics of Malpighiaceae: evidence from plastid $r b c L$ and mat K sequences. American Journal of Botany 88: 1847-1862.

ChaKRAPANI, P. and B. Raj. 1971. Pollen morphological studies in the Burmanniaceae. Grana 11: 164-179.

Chanda, S., S. Nilsson, and S. Blackmore. 1988. Phylogenetic trends in the Alismatales with reference to pollen grains. Grana 27: 257-272.

DajOz, I., I. Till-Bottraud, and P. H. GouYon. 1991. Evolution of pollen morphology. Science 253: 66-68.

Doyle, J. A., P. BYgrave, and A. LE ThOMAs. 2000. Implications of molecular data for pollen evolution in Annonaceae. Pp. 259-284 in Pollen and spores: morphology and biology, eds. M. M. Harley, C. M. Morton and S. Blackmore. Kew: Royal Botanic Gardens.

FuRNESS, C. A. and P. J. RudalL. 1998. The tapetum and systematics in monocotyledons. Botanical Review 64: 201-239.

— and _ 1999. Microsporogenesis in monocotyledons. Annals of Botany 84: 475-499.

and - . 2000. The systematic significance of simultaneous cytokinesis during microsporogenesis in monocotyledons. Pp.189-193 in Monocots: systematics and evolution, eds. K. L. Wilson and D. A. Morrison. Melbourne: CSIRO.

- and - 2001. Pollen and anther characters in monocot systematics. Grana 40: 17-25.

and — 2004. Pollen and aperture evolution-a crucial factor for eudicot success? Trends in Plant Science 9: 154-158.

Garcia, M. B., R. J. Antor, and X. Espadaler. 1995. Ant pollination of the palaeoendemic dioecious Borderea pyrenaica (Dioscoreaceae). Plant Systematics and Evolution 198: 17-27.

HuYSMANS, S., G. El-GHAZALY, and E. SMETS. 1998. Orbicules in angiosperms. Morphology, function, distribution, and relation with tapetum types. Botanical Review 64: 240-272. 
MAdDison, W. and D. MAdDison. 2001. MacClade 4 software. Sunderland: Sinauer Associates.

Prain, D. and I. H. BuRKILL. 1936. An account of the genus Dioscorea in the East, part 1: the species which twine to the left. Annals of the Royal Botanic Gardens, Calcutta 14(1): 1-210.

Punt, W., S. BlaCKMORE, S. NiLSSON, and A. Le ThOMAS. 1998. Pollen and spore terminology, P. Hoen, ed. Internet version (http:// www.biol.ruu.nl/ palaeo/glossary/).

Raz, L., P. Schols, V. Cielen, C. A. Furness, P. Wilkin, and E. SMETS. 2001. A palynological survey of New World Dioscoreaceae. Pp. 37 in Abstracts, Symposium on Tropical and Subtropical Palynology (America-Africa). Havana: Jardin Botanico Nacional.

RESSAYRE, A. 2001. Equatorial aperture pattern in monocots: same definition rules as in eudicots? The example of two species of Pontederiaceae. International Journal of Plant Sciences 162: 1219-1224.

- C. Raquin, A. Mignot, B. Godelle, and P. H. Gouyon. 2002. Correlated variation in microtubule distribution, callose deposition during male, post-meiotic cytokinesis, and pollen aperture number across Nicotiana species (Solanaceae). American Journal of Botany 89: 393-400.

RüBSAMEN, T. 1986. Morphologische, embryologische und systematische Untersuchungen an Burmanniaceae und Corsiaceae. Dissertationes Botanica 92: 1-310.

Rudall, P. J., C. A. Furness, M. W. Chase, and M. F. FAy. 1997. Microsporogenesis and pollen sulcus type in Asparagales (Lilianae). Canadian Journal of Botany 75: 408-430.

Sauguet, H. and A. Le Thomas. 2003. Pollen diversity and evolution in Myristicaceae (Magnoliales). International Journal of Plant Sciences 164: 613-628.

Schols, P., S. Dessein, C. D'HONDT, S. HuYsmans, and E. SMETS. 2002. Carnoy: a new digital measurement tool for palynology. Grana 41: 124-126.

, C. A. Furness, P. Wilkin, S. Huysmans, and E. SMets, 2001. Morphology of pollen and orbicules in some Dioscorea (Dioscoreaceae) species and its systematic implications. Botanical Journal of the Linnean Society 136: 295-311.

E. SMETS, V. Cielen, and S. HuYSMANS. 2003. Pollen morphology of Dioscorea (Dioscoreaceae) and its relation to systematics. Botanical Journal of the Linnean Society: 143: $375-390$

C. D'HONDT, K. Geuten, V. MerckX, S. Janssens, and E. SMETS. 2004. MorphoCode: coding quantitative data for phylogenetic analysis. Phyloinformatics 1: 4.

Segarra-Moragues, J. G. and P. CatalÁn. In press. Species boundaries and population divergence in the Pyrenean endemic relict genus Borderea (Dioscoreaceae) as revealed by microsatellite (SSR) and other hypervariable markers. In J. T. Columbus, E. A. Friar, C. W. Hamilton, J. M. Porter, L. M. Prince, and M. G. Simpson [eds.]. Monocots: Comparative biology and evolution. 2 vols. Claremont: Rancho Santa Ana Botanic Garden.

SIMPSON, M. G. 1987. Pollen ultrastructure of the Pontederiaceae. Grana 26: 113-126.

Su, P. 1987. Pollen morphology of Dioscorea in China. Acta Phytotaxonomica Sinensis 25: 357-365.

THIELE, K. 1993. The holy grail of the perfect character: the cladistic treatment of morphometric data. Cladistics 9: 275-304.

VAN CAMPO, M. 1976. Patterns of pollen morphological variation within taxa. Pp. 125-135 in The evolutionary significance of the exine, eds. I. K. Ferguson and J. Muller. London: Academic Press.

van DER HAm, R. W. J. M., W. L. A. Hetterscheid, and B. J. vaN HeUven. 1998. Notes on the genus Amorphophallus (Araceae) -8. Pollen morphology of Amorphophallus and Pseudodracontium. Review of Palaeobotany and Palynology 103: 95-141.

Wilkin, P., P. Schols, M. W. Chase, K. Chayamarit, C. A. FurNESS, S. Huysmans, F. Rakotonasolo, E. SMETS, and C. THAPYAI. 2005. A plastid gene phylogeny of the Yam genus, Dioscorea: roots fruits and Madagascar. Systematic Botany 30: $\mathrm{XX}-\mathrm{XX}$.

XIFREDA, C. C. 2000. Evaluation of pollen and vegetative characters in the systematics of South American species of Dioscorea (Dioscoreaceae) Pp.488-496 in Systematics and evolution of monocots. Proceedings of the $2^{\text {nd }}$ International Monocot Conference, eds. K. L. Wilson and D. A. Morrison. Melbourne: CSIRO Publishing.

ZAVADA, M. S. 1983. Comparative morphology of monocot pollen and evolutionary trends of apertures and wall structures. Botanical Review 49: 331-379.

\section{APPENDIX 1}

Specimens examined.

D. alatipes Burkill \& H. Perrier-Madagascar, Phillipson 3208 (K) D. antaly Jum. \& H. Perrier-Madagascar, Wilkin et al. 1103 (K). D. arcuatinervis Hochr.-Madagascar, Caddick et al. 309 (K). D. bemarivensis Jum. \& H. Perrier-Madagascar, Phillipson 3027 (K). D. birmanica Prain \& Burkill-Burma, Lace 6184 (K). D. brachybotrya Poepp.-Chile, Comber 462 (K). D. buchananii Benth.-Zimbabwe, Biegel 2893 (K). D. bulbifera L.-Thailand, Wilkin 864 (K). D. cirrhosa Lour-China, Shiu Ying Hu 9970 (K). D. coriacea Humb. \& Bonpl. ex Willd.-Ecuador, Fleming 143 (K). D. daunea Prain \& BurkillThailand, Middleton \& Parnell 1468 (K). D. debilis Uline ex KnuthBrazil, Harley et al. 20871 (K). D. decipiens Hook. f.-Thailand, Wilkin 860 (K). D. dumetorum (Kunth) Pax-Malawi, Wilkin \& Tawakali 786 (K). D. elephantipes Engl._S. Africa, Archibald 8014 (K). D. esculenta Burkill-Mollucas, Beguin 2093 (K). D. fandra H. PerrierMadagascar, Caddick et al. 324 (K). D. galeottiana Kunth-Mexico, Diaz Vilchis 1228 (BR). D. gillettii Milne-Redh.-Ethiopia, Friis, Gilbert \& Rasmussen 943 (BR). D. glabra Roxb.-Thailand, Wilkin 892 (K). D. hamiltonii Hook. f.-Thailand, Wilkin et al. 886 (K). D. hexagona Baker-Madagascar, Wilkin et al. M960 (K). D. karatana Wilkin-Madagascar, Wilkin et al. M947 (K). D. maciba Jum. \& H. Perrier-Madagascar, Wilkin et al M964 (K). D. membranacea PierreThailand, Middleton \& Parnell 1468 (K). D. namorokensis WilkinMadagascar, Wilkin et al. 1118 (K). D. nipponica Makino-Togasi 1214 (BR). D. ovinala Baker-Madagascar, Wilkin et al. 1115 (K). D. pentaphylla L.-Thailand, Boulanger 1109 (K). D. preussii Pax-Nigeria, Pilz 1801 (K). D. proteiformis H. Perrier-Madagascar, McPherson et al. 14203 (K). D. pseudo-nitens Prain \& Burkill-Thailand, Garrett 781 (K). D. pyrenaica Bub. \& Bordere ex Gren.-Spain, Sandwith 4745 (K). D. sambiranensis R. Knuth ssp. ambrensis H. PerrierMadagascar, Perrier de la Bathie 17551 (K). D. sansibarensis PaxTanzania, Faden et al. 96/12 (K). D. schimperiana Hochst.-Malawi, Wilkin \& Tawakali 763 (K). D. soso Jum. \& H. Perrier-Madagascar, Wilkin et al. 1105 (K). D. sylvatica Eckl.-Zimbabwe, Chase 7939 (K). D. wallichii Hook.f.-Thailand, Wilkin 1078 (K). D. zingiberensis C.H.Wright-China, Wilson 2921 (K).

Tacca artocarpifolia Seem.-Madagascar, Caddick 305 (K). Tacca chantrieri André-Chase 175 (K). Tacca integrifolia Ker Gawl.-Thailand, Boyce 1074 (K). Tacca leontopetaloides Kuntze-Thailand, Wilkin et al. 817 (K). Tacca palmata Blume-Malaysia (cult.), Boyce 1982 (K). Tacca palmatifida Baker-van Balgooy 3586 (K). Tacca plantaginea Drenth-PS-TA1 (LV) 